\title{
Boko Haram,Peace, Security and Development in North-East Nigeria: A Refractory Expedition
}

\author{
Oyekanmi Omosefe $^{1} \quad$ Taiwo Patricia A ${ }^{2}$ (Ph.D) \\ 1.Nigerian Institute for Social and Economic Research (NISER) \\ 2.Department of Sociology, Faculty of the Social Sciences, University of Ibadan
}

\begin{abstract}
The atrocious crimes leashed on North Eastern Nigerians evident in brutal killings, rapes, kidnap and violence against humanity by the Boko Haram sect for 16years, is not only devastating but also brings critical narratives to the fore. The threats this sect has posed overtime to the level of peace, security and development of the nation generally, questions the role, agenda and essence of governance in Nigeria especially at the federal level. Available studies bothering on insurgency in the North Eastern region of Nigeria, seem to pay negligible attention to the interconnectedness between peace and development in that region. Applying the democratic peace theory, this paper sets to examine the link between peace, security and development since the formation of Boko Haram in 2002, with particular reference to Borno, Adamawa and Yobe states of Northern Nigeria. The secondary data sources were utilized through theoretical and historical analysis to access, interpret and discuss the findings. The paper submits that the security situation in the region is influenced by the already existing economic dislocation, volatile political terrain, religious insensitivity etc and has adversely affected the peaceful co-existence, security and overall level of development in the region. While a military intervention in curbing this mayhem is expedient, this paper suggests that the assurance of security and overall development of the region should be a top-notch agenda of government in order to fortify any resolve for peace not only in the North east but also in every region in Nigeria.
\end{abstract}

Keywords: Peace, Security, Development, Boko Haram, North-East Nigeria

Word Count: 245

DOI: $10.7176 / \mathrm{JPID} / 49-05$

Publication date: April $30^{\text {th }} 2019$

\section{Introduction}

The wanton loss of lives, destruction of properties, kidnappings, and the many internally displaced persons in Nigeria's North East, factored by the activities of the Boko Haram group has not only attracted concerns locally and globally, but has in the most part, brought to the fore, the contempt on humanity by humanity in a $21^{\text {st }}$ century era. The Islamic sect turned violent after the death of their leader Mohammed Yusuf in police custody in 2009. Largely, this insurgent group have raked their havoc more in Nigeria's volatile and porous North East, with Adamawa, Yobeand Borno being the most hit.The group Jama'atulAlhulSunnahLidda' watiwal Jihad (people committed to the propagation of the prophet's teachings and jihad) (Abolurin, 2012:261) was established in 2002 in Maiduguri, Borno's capital as an Islamic group called Boko Haram. The word 'Boko' (Hausa) means 'book', considered to be Western and Haram (Arabic) means forbidden. Thus, Boko Haram in Hausa Language means "western education is forbidden" (Gilbert, 2014). Conceivably, with the violent destruction of lives and property, both in the mosque, church, schools, markets and major social gatherings, Islamic groups are observed to have risen beyond its scope of western education. Similarly, means of livelihood, education, health care system and general development have been stalled. The region is now depleting as a slaughter slab, as the news of death, rape and kidnapping in that region does not raise eyebrow anymore. With not all of the abducted chibok girls being released, the terrorist group yet again abducted 110 Dapchi girls on February 19, 2018, (WFP:2018). Although over $90 \%$ of the girls were released, howbeit, the situation in North Eastern Nigeria highlights a missing link between peace, security and development. According to Richard Engel, a legitimate grievance against the State who refuses to compromise then justifies insurgent's actions against the state. In his words,:

"insurgencies are easy to make and hard to stop. Only a few ingredients need to combine to create an insurgency, like oxygen and fire, they're very common and mix all too often. The recipe is simply a legitimate grievance against a state, a state that refuses to compromise, a quorum of angrypeople, and easy access to weapons"

Hence, many trivial but yet salient factors have nurtured the north east as a bee-hive for terrorist activities. The failure of the Nigerian leadership, weak institution, poverty, corruption and gross underdevelopment, which dolorously, is replicated in every region of the Nigerian space, has indeed created a wide margin between peace and development. This paper therefore seeks to examine the nexus between peace, security and development and how a long term approach at advancing development in the region poses as a veritable tool in curbing Boko Haram activities and any other violent insurgent group grieved by the State. 


\section{Conceptualization}

\subsection{Peace}

As complicated as the concept of peace is, meaning different things to different people it is almost preferable to war and can and must include not only the absence of war but also the establishment of positive, life-enhancing values and social structure (Galtung, 2013). Douglas Noll and Johan Galtung at separate accounts, made distinctions between positive and negative peace, For Galtung, Positive peace refers to a social condition in which exploitation is minimized or eliminated and in which there is neither overt violence nor the more subtle phenomenon of underlying structural violence, while historically, negative peace denotes the absence of war and other forms of large scale violent human conflict.

\subsection{Development}

To some school of thoughts, development means the liberalization of economies while to other school of thought, it encompasses a continuous change in a variety of aspects of the human condition. Like the later school of thought, Sen(1999) has given a broader narrative to the concept of development. He argues that development must be judged by its impact on people and the distribution success of this impact and not just in mere figurative termsin the society. Seers on the other hand, conceive development as the process of economic and social transformation that is based on complex, cultural and environmental factors and their interactions (Dudley, 1969). To him, the questions to ask about a country's development are therefore; what has been happening to poverty, what has been happening to unemployment, what has been happening to inequality? He also mentioned adequate educational levels, freedom of speech, true economic and political independence as human potentials. But some governments are themselves the main obstacles to development as a structural societal change (Dudley, 1967). Hence, the concept of development in this discourse, is a combination of Sen and Seers's position which is considered to exist not only in the presence of progressive values but creating well circulated and tangible impacts through the capacity of the system to provide the enabling environment for that continued wellbeing. In essence, values must be drawn from government.

\subsection{Security}

The multi-dimensional and diverse nature of the concept of security, makes it expedient to underscore its contextual usage in this paper. Security basically is the absence of threat and fear. This could be fear from hunger, environment, people, state of living and death. Similarly,Fischer and Green, opines thatsecurity implies a stable, relatively predictable environment in which an individual or group may pursue its ends without disruption or harm and without fear of such disturbance or injury' (2004). Hence, the concept of security in this paper suggests that through commitments, a certain level of trust is earned from the state government, subsequently, citizens deprived of security (i.e. the absence of trust as a result of failed commitments from state actors) pose as a potential threat to peace and development.

\section{Theoretical Consideration}

\subsection{Democratic Peace Theory (DPT)}

The democratic peace theory posits that global democracy will provide a solid foundation for global peace, hence two democratic states are less likely to go to war compared to two undemocratic states and arguably, democratic states never go to war (Mello; 2014). The standpoint of this paper supports the normative logical argument of democratic peace that posits that democratic states are subjected to social and cultural norms that advances equal representation, justice, respect for human rights, development, and peaceful resolution of conflicts. According to Ohlson and Soderberg (2016) the synchronization of conflict resolution, democracy and state making, postulates that weak states are more prone to end up in intra-state (civil) war than are strong states. The duo, further suggested that democratic government by design accommodates protest, but also offers nonviolent measures of voicing grievances and expressing protest as well as devising techniques to arrest violent protest. In light of this, it is believed that peace and its sustainability through development can only thrive in a stable and mature democracy were government are justly accountable to her citizenry, promoting free and fair elections, resolving disputes through peaceful means and upholding justice above all. Hence this theory supports the argument that the security situation in the region is influenced by the already existing economic dislocation, volatile political terrain, and gross failure of the state system. According to Ahmad Salkida, a close ally of Mohammed Yusuf, the late founder of the sect;

"Were it not for a country like Nigeria, where government has failed to provide basic life support for its citizens, late Yusuf may have never thrived. A functional environment with opportunities for all, equal justice for all, fairness to all and governed by leaders that are responsible for their people, the rude and retrogressive teachings of late Yusuf would have not received the attention of about a million followers all over the north" (Abusidiqu bloq:2014) 
As such, the absence of these values, has extrapolated full scale violence in Nigeria's North East,a region that has suffered so much neglect, poverty and underdevelopment (Osaretin: 2015). A study conducted by the UN shows that poverty in 12 Northern states is twice the impact of poverty in other parts of Nigeria (Johnnie :2012)

\section{DISCUSSION}

Boko Haram is not the only security threat to Nigeria's national security. There has been several militia groups destabilizing peace and security. From the Maitatsine militia in the 80s to the Bakassi Boys and the Movement of the Actualization of Sovereign State of Biafra (MASSOB) in 1999, and IPOB in 2014, to the Niger delta militants in 2006, then the Boko Haram fundamentalist sect in 2009. However the Boko Haram insurgents stands out in its brutality and disastrous effect, hence, the spate of deadly attacks perpetrated by Boko Haram insurgents in Nigeria has informed many narratives to the discourse. Using Robert Jackson's inference of negative sovereignty (1986), the Nigerian state has not managed security checks and governance accordingly. With porousborders, there has not been any substantial policy implementation on border security and management. This has greatly compromised security intelligence and challenged economic and governance development, as the influx of illegal small and light weapons is continually on the rise.

There is a common theory supporting the claim that the boko haram sect was sponsoredby northern politicians to make Jonathan's administration look bad. This theory is championed by southern politicians who believe that the people from the core north has taken Nigerian leadership as their birth right and to show their disdain for a southern leadership, Boko Haram became an instrument by northern elites, for destabilizing the country and to make the country ungovernable for Goodluck Jonathan. Again, there is another twist to this theory. This school of thought posits that Goodluck Jonathan, a southerner, sponsored the Boko Haram insurgency in other tomobilize support from the south and Christians or to weaken and de-populate the north ahead of the 2015presidential election. The position of this conspiracy theory rests on an acclaimed false pretense by the Jonathan administration to give an impression of his administration as an underdog been oppressed by the North via the Boko Haram insurgents. Thus, the presidency can galvanize support from southern and Christian populace. Major elites from the north including former governor of Adamawa state, Murtala Nyako have legitimized this theory (Adibe:2011). However this theory are limiting in explaining the reasons behind the insurgency in the north east. Firstly, Jonathan was the vice-president under Yaradua a northern, when Boko Haram unleashed terror on the Nigerian state in 2009. Secondly, testimonies by arrested Boko Haram suspects have not suggested the involvement of Goodluck Jonathan in Boko Haram terrorism.

Others perceive the insurgency as a reflection of political Islamism, where the fear of religion supremacy gives rise to pockets of uprising against the state (Osaretin: 2015). State governments and political elites dabble religion with governance, at the peril of health, education, security, justice, etc. Some other intellectuals, is of the view that the BokoHaram insurgency is a factor of a fundamental belief system and religious fundamentalism (Malasowe: 2016).Johnnie Carson (2012), Ahmad Salkida (2014) at separate account suggests that the offspring of Boko Haram is a reflection of the social economic failure of the state system. They assert that there is a connection between the rising atrocities by Boko Haram and the level of state neglect of citizens by government, thus,the resultant cost is that it creates the necessary condition for radical Islam to thrive and by extension the rise of other marginalized groups (Isa 2010: 329). According to Prof Gambari (2012) an under Secretary General, special adviser to the secretary General of the United Nations, an analysis on girl child education, suggests that the North East with 20 percent has the lowest enrolment rate in the country, as against 85 percent in the South East, 75 percent in the South-South and 25 percent in the North West. To further buttress this assertion, Nigeria's vice-president Prof YemiOsinbajo affirmed that, the region has the lowest school enrolment in the country as well as the highest infant and mortality rate in the country. In effect the poverty, underdevelopment and marginalization of the region should not serve as a platform for future engagement with the region (Vanguard newspaper:2015). Lolio's assertion further underscores the tone of this paper. He opines that

"it is significant to know that the root causes of the insurgency often relate to a long cloudy set of problems culminating into uncontrolled grievances and exploding violence. Such problems are socio-economic and political, that is why insurgencies are more rampant in underdeveloped countries or countries engulfed by corrupt regime, ethnicity, social prejudices as religious and disparities in the distribution of resources or even lack of it (2013)"

Subsequent on the above, the Franz Fanon's (2001) categorization of the "Wretched of the Earth" comes to the fore in analyzing the emergence of the terrorist group. The sheer need to meet basic needs in the face of harsh realities has informed violent enduring conflict. An annual GDP growth rate for over a decade shows that the north has one of the poorest populations in Nigeria, and the highest poverty rate worldwide by a UNDP report in 2012. Also, the North East and North West have become popular with an alarming rate of prostitution and drug abuse.The reason behind this staggering fact is not unconnected to the many uneducated Northernand 
unemployed youths. The insecurity and underdevelopment of the North emboldened with, bad leadership and gross mismanagement of national revenue has made the North-East susceptible to terrorist activities

Consequently, the Boko Haram insurgency in the north east and by extension violent extremist activities in Nigeria cannot be bagged as a response to global terrorism. The Nigerian state has constructed fertile ground for conflict and violence.

\section{BORNO, ADAMAWA AND YOBE IN THE EYE OF THE STORM}

The pertinent security issue that has bedeviled some states in the North East for the past nine years has brought great concerns to not only state governments of that region, but the Nigerian government as a whole. With scores of death recorded, many internally displaced, thousands of girls and women abducted and raped, etc. Amidst the deteriorating security situation in the country, sadly, the North East is confronted with daunting developmental challenges which pose serious threat to socio-economic development. According to OCHA (2018), there are 7.7 million people in need of humanitarian assistance in Borno, Adamawa and Yobe states.2.3 million People have been displaced by the conflict since May 2013, another 250,000 have left Nigeria and fled into Cameroon, Chad or Niger, with over 17,000 people killed by Boko Haram sect (Papka: 2017). Similarly, evidences in Nigeria shows that the number of those in poverty has continued to increase and Borno state is acknowledged to be at the forefront. Ninety-eight percent of the ten and half million Nigerian youngsters out of school who are predominantly girls, are in Nigeria's poorer north (USAID 2015-2020).As a result of the terrorist attacks such as ambushing vehicles along major market routes and attacking communities and markets, over 43,000 people are experiencing famine (Cadre Hamonise:2017). According to Oxfam deputy director in Nigeria, Constant Tchona, out of the over 5.8 million people likely to die from malnutrition in the North-East, 5.2 million are in Adamawa, Borno and Yobe states alone(2017).For instance, in Borno state, agrarians have fled in their millions for safety to neighboring Cameroon and chad. Almost one in five children is estimated to be suffering from severe acute malnutrition. With an alarming number of severemalnourished children expected to reach 450,000 in Borno, Adamawa and Yobe states (UNICEF:2017), hence, sparking up a numberof communicable diseases in the internally displaced camps, which further problematizes humanitarian assistance. Indeed the insurgency in Borno, Adamawa and Yobe has posed development as a recalcitrant agenda.

Ideally, education is the swivel of any developed society, thus the reason societies give adequate attention to educational growth and development. However, the story appears different in northern Nigeria, where over 30 percent of school aged children are shut out of basic education (Natalie.L: 2011). Mercy Corps report (2016), affirms that with 10.5 million children out of school, Nigeria has the largest population of children who are out of school globally. Similarly, an assessment by creative associates international in 2011 revealed that 70 percent of Bauchi students scored zero on the oral reading fluency task.Furthermore, most girls in the north never complete primary school. According to MuhammedJabbiKilgori, there is adisconnect between policies made and their implementation. He opined that weak implementation of policy, inadequate political will, lack of proper budgetary allocation and fund release for basic education, as well as no existing reading policy, a lack of teaching quality and motivation among teachers all amounts to a draw back for education in the north (Natalie.L: 2011)

For an Adamawa indigene,lawyer, former presidential aspirant and EFCC chair, NuhuRibadu suggests the unlawful atrocities of the Almajiri school system, evident in their human rights abuse of the Nigerian child,all stagnates development in the north. As he succinctly puts,

"Look at all the indices in the world today. We are the worst. How can we continue to deny ourselves our future? (Pulse.ng, 2018.)

The Almajiris are the victims and the first point of mischief makers. Consequent on this, the educational system in Northern Nigeria has festered conscripts for Boko Haram insurgency. To compound this quagmire, the destructive nature of the boko haram sects in this region, have left the educational and health system in a skeletal form. According to the UNICEF 2018 Humanitarian Response Plan for Northeast - Adamawa, Borno and Yobe,

"Only half of the 755 health facilities in Borno remain functional and nearly

1,400 schools have been DAMAGED or destroyed, many of these schools are unable to reopen for safety reasons. Over one million children are currently out of school and the protracted crisis has also compromised the physical safety and psychosocial well-being of 2.5 million children in north-east Nigeria, who require immediate assistance. An estimated 400,000 children in 14 local government areas in Borno will be severely malnourished in 2018. Five local government areas in Yobe are experiencing global acute malnutrition rates of 10 to 20 per cent. An estimated 1.5 million people lack access to safe water - 940,000 in Borno, 480,000 in Adamawa and 80,000 in Yobe, as a result, vulnerable children are becoming acutely malnourished after repeated bouts of diarrheal disease," (UNICEF:2018) 
Furthermore, the adoption of over 200 Chibok girls in April 14, 2014 and the 110 Dapchi girls adoptions in 2017 has increased distrust in the security of education particularly among thegirl child. Basically, unemployment, injustice, endemic poverty, corruption, bad and insensitive leadership, and loss of faith and hope in the government exacerbated the Islamic fanaticsdisenchantment with the country, particularly at the state and local government levels, where these governments were indifferent to the societal problems. Although, the Islamic sect started off as antagonizing the anti-development indices of the Nigerian government, claiming that western education has abetted corruption, lopsided justice system and general underdevelopment, however, its ideology appears hijacked and remains unclear as the wanton destruction of lives and property, particularly in these three states, tilts the group more as terrorist with an identity of what Hannah Arendt called the "banality of evil" (1963). Essentially, this notion suggests that the Nigerian security paradox is not a reflection of one insurgent group but rather a posture of a number of missing fundamentals. Such that, the Nigerian state has conformed people based on accepting their actions normal even when such action are abnormal. The Nigerian government declared a state of emergency in Adamawa, Borno and Yobe states in 2015 and some territories have been regained (vanguard: 2015), this however has not revamped the already ailing economic and development situation that has distorted peace and security in the North-East.

In effect, even after isolating the Boko Haram insurgent group, Nigeria still remains enmeshed in her security challenge. In other words, Boko Haram as an ideology provides the stimulus for the aggrieved, subjected to endemic poverty, unemployment, and injustice in a country blessed with human and natural resources. The deprivation, inequity, poverty and youth unemployment has intensified the Boko Haram insurgency. Hence boko haram is just a window for Nigerians who witness leaders stealing and diverting national wealth to personal gains at the dearth of basic needs for the general populace. Although, the insurgency in the north east has severely deteriorated the already underdeveloped states, however, conscription in the first place thrived due to poverty, unemployment and gross highhandedness of the political class. Olojo and Idowu (2013) at separate accounts corroborates this assertion, affirming that brutal radicalism, enrolment and support for Boko Haram have been dependent oneconomic deprivation, as well as ethnicity, poverty, inequality, crises of the state, political culture and institutional failure as significantly contributed to Boko haram insurgency.

\section{CONCLUSION AND RECOMMENDATION}

For over a decade, the dastardly activities of Boko Haram insurgency and many other negative rhetoric have trailed the news. Nigeria has taken the front space in human right abuse, outrageous number in internally displaced persons, out of school children; kidnap cases, girl and women molestation, suicide bombing and mass murder. Ideally, since the above listed are indicators of a war-torn state, the question that then comes to the fore, bothers on if Nigeria is at war. The nexus between peace, security and development cannot be overemphasized in attending to violent ridden situations, given that development cannot thrive in an unstable clime. Kofi Annan, (former Secretary General of the United Nations) in a foreword to human security and new diplomacy, established a partial diversion of security from the conventional knowledge of military defense to a broader framework of security.

He asserted that "During the cold war, security tended to be defined almost entirely in terms of military might and the balance of terror. Today we know that 'security means far more than the absence of conflict. We also have a greater appreciation for non-military sources of conflict. We know that lasting peace requires a broader vision encompassing areas such as education and health, democracy and human rights, protection against environmental degradation, and the proliferation of deadly weapons. We know that we cannot be secure amidst starvation, that we cannot build peace without alleviating poverty, and that we cannot build freedom on foundations of injustice. These pillars of what we now understand as the people-centered concept of "human security' are interrelated and mutually reinforcing",

Similarly Luke. J, (2014) reiterated Annan's view point, when he affirmed that:

"...The world is entering a new era in which the very concept of security will change - and change dramatically. security will be interpreted as: security of people, not just territory. security of individuals, not just nations. security through development, not through arms. security of all the people everywhere - in their homes, in their jobs, in their streets, in their communities, in their environment."

The unending debacle in the North-East will remain an impasse, until the Nigerian government tackles poverty, insecurity, unemployment and underdevelopment. In Paul Collier's view, basic standard solutions to development, globally and locally will remain futile as long as countries are trapped under these four strings; the conflict trap; the natural resources trap; the trap of being landlocked with bad neighbours; and the trap of bad governance in a small country (Collier,2007). These four traps in his view, characterizes a failed state. What this 
portends, is that as long as states fail to provide public services and a legitimate way out of these traps, it can lead to civil unrest, violence from communities and insurgent groups like the Boko Haram terrorist sect that now serves as a shield for grieved fanatics to vent their been marginalized.

While short term approach, such as effective military presence, declared state of emergency, adequate provision for the internally displaced camps, agricultural development, food expansion and basic health services for the victims of the insurgency is expedient, any long term approach isolated from legitimate governance, equity, justice, education, gainful employment and general development of the region will at best be a refractory expedition in restoring peace.

Summarily, to tackle the Boko haram insurgency, government must be accountable to its citizenry with evident deliveries that assures the masses of sustainable peace, security and development

\section{REFERENCES}

Abusidiqu, 2014, The Genesis of Boko Haram: An Insider's Account, abusidiqubloq,www.abusidiqu.com/thegenesis-of-boko-haram-an-insiders account/May 9, 2014

ACAPS Briefing Note: Food Security and Nutrition in Northeast Nigeria - 12 April 2017 https://www.acaps.org/sites/acaps/files/products/files/20170412_acaps_briefing_note_nigeria_food_securit y and nutrition.pdf

Adibe, Jideofor (2011) 'Beyond Boko Haram' (Abuja, Daily Trust), September 1, 2011

Amartya. S, 2000, “Development as Freedom', New York, Anchor Books

Arendt, Hannah (1963). "EICHMANn IN JERUSALEM": A REPORT ON THE B ANALiTy of EVIL

Collier, P., 2007, 'The Bottom Billion: Why the Poorest Countries are Failing and What can be

Done About it", Oxford University Press, Oxford

Dan. R, 2015, 'Democratic Peace Theory', Oxford bibliography

Fanon, Frantz (2001) “WRETCHED OF THE EARTH” (London: Penguin Classics).

Fischer, R . J and Green, G . ( 2004 ) Introduction to Security Boston, MA:

Godwin.M, 2016, A Review of Studies on Boko Haram Insurgency: Positions and Counter-Positions, International Journal Of Political Science And Research, Vol. 4(7), pp. 276-285

Johnnie. C, 2012, Daily Trust, 6 April 2012: 29

Johan. G, 1969, 'Violence, Peace and Peace Research', journal of peace research 6(3) pp 167-191

Mello.P.A, 2014, 'The Dual finding of Democratic Peace', Sage encyclopedia ofwar:Social Science Perspectives

Liolio S.E, 2012, Rethinking Counterinsurgency: A case Study of Boko Haram in Nigeria. European Peace University Stadschlaining, Austria. .

Luke. J, 2014, 'A Critical Evaluation of the Concept of Human Security', E-International Relations Students online Journal, assessed in http://www.e-ir.info/2014/07/05/a-critical-evaluation-of-the-concept-of-humansecurity/ on Aug 16 ${ }^{\text {th }}, 2017$

Mercy corps, 2016, A brighter future starts with an education, pub $31^{\text {st }}$ Aug, 2016 in https://reliefweb.int/report/nigeria/brighter-future-starts-education

Mustapha et al, 2013, Harnessing The Economic Potentials Of Borno State For Poverty Alleviation In Nigeria, International Journal of Research In Agriculture and Food Sciences, Vol 2. No 5

Natalie.L,2011, All Hands On Deck' To Strengthen Education In Northern Nigeria, Say Experts At Cies, Creative, https://www.creativeassociatesinternational.com/stories/hands-deck-strengthen-educationnorthern-nigeria-says-expert-cies/

Osaretin.I, 2015, Boko Haram and the Nigerian State: a Different Perspective, Glocalism, Journal of Culture, Politics and Inovation, vol 3Butterworth-Heinemann.

Papka. M, 2017, The effect of Boko Haram activities on educational development in Madagali local government area of Adamawa State, International Journal of Academic Research and DevelopmentVol. 2 No. 1

Punch Newspaper, 2018, Breaking the vicious grip of poverty in the North, pub April 29, 2018, https://punchng.com/breaking-the-vicious-grip-of-poverty-in-the-north/

Ribadu. N, 2018,'Northern Nigeria is the most backward in the world' pulse.ng, pub 15 ${ }^{\text {th }}$ Aug, 2018 in https://www.pulse.ng/news/local/ribadu-northern-nigeria-is-the-most-backward-in-the-worldid8729843.html

Seers, D, 1969, 'the meaning of development', IDS communication 44, institute of development studies

Seers, D, (1967), 'the meaning of development', IDS communication 44, Brighton,UK: institute of development studies

UNCHR, 2016, To defeat Boko Haram, the Nigerian government must tackle poverty, insecurity and underdevelopment,https:/www.premiumtimesng.com/news/top-news/218461-nigeria-must-tackle-povertyunderdevelopment-defeat-boko-haram-unhcr.html

Wale.O, dailypost.ng, 2018, Boko Haram: 1,400 Borno schools destroyed, 2.5m kids at risk in North-east - UNICEF, Feb 2, 2018, http://dailypost.ng/2018/02/02/boko-haram-1400-borno-schools-destroyed-2-5m-kids-risk-north-east- 
unicef/

WFP Nigeria Situation Report \#26, 1 - 28 February 2018, Assesedjuly 17,2018 in https://reliefweb.int/report/nigeria/wfp-nigeria-situation-report-26-1-28-february-2018

Yemi. O, 2015, Poverty, Underdevelopment in North should not define region's future, pub in Vanguard Newspaper, September 12, 2015

https://www.acaps.org/sites/acaps/files/products/files/20170412_acaps_briefing_note_nigeria_food_security_an d_nutrition.pdf

https://www.unocha.org/nigeria/about-ocha-nigeria

https://www.vanguardngr.com/2012/02/boko-haram-how-northern-leaders-underdeveloped-the-north/

https://www.vanguardngr.com/2015/09/poverty-underdevelopment-in-north-should-not-define-regions-futureosinbajo/, Sep 12, 2015. 